\title{
Effects of Zataria multiflora essential oil on the germinative cells of Echinococcus granulosus
}

\author{
Nasim Kowsari ${ }^{1}$, Mohammad Moazeni ${ }^{*}$ (D) and Ali Mohammadi ${ }^{2}$
}

\begin{abstract}
Background: Novel and more efficient compounds are urgently required for medical treatment of cystic echinococcosis (CE). Germinative cell culture of Echinococcus granulosus could be used for anti-echinococcosis agent tests and other biological studies on CE. This study was performed to establish an in vitro cell culture model for E. granulosus germinative cells and to evaluate the lethal effect of Zataria multiflora essential oil (ZMEO) on the cultured cells.

Methods: The inner surface of germinal layers of CE cysts was scraped, and the obtained materials were trypsinized to obtain a suspension of single germinative cells. Medium 199 was used as the basic culture medium and was supplemented with fetal bovine serum, 2-mercaptoethanol, L-cysteine, L-glutamine, glucose, sodium pyruvate, hydatid fluid, amphotericin B and antibiotics. The cells were cultured at a concentration of $10^{4}$ cells $/ \mathrm{ml}$ of culture medium and incubated at $37^{\circ} \mathrm{C}$. The culture medium was replaced every 7 days. Chemical composition of ZMEO was identified by GC-MS analysis. ZMEO was tested at concentrations of $0.5-8 \mathrm{mg} / \mathrm{ml}$. Viability of the cells was assessed by trypan blue exclusion assay.
\end{abstract}

Results: A significant increase in the cell number was evident at 20,30 and 45 days after cultivation. At 45 days of cultivation, the number of cells was approximately five-fold higher than on the first day. In GC-MC analysis, carvacrol, $p$-cymene, g-terpinene and thymol were found to be the main compounds of ZMEO. The lethal effect of ZMEO on the germinative cells at concentrations of 6,7 and $8 \mathrm{mg} / \mathrm{ml}$ was $100 \%$ after 60,25 and $7 \mathrm{~min}$ of exposure, respectively.

Conclusions: At 45 days of cultivation, the cell concentration was suitable for the desired in vitro experiments. A high lethal effect of ZMEO on the germinative cells of E. granulosus may be considered an opportunity for the introduction of a novel, more effective and safer therapeutic agent for treatment of CE using an herbal product.

Keywords: In vitro, Cell culture, Echinococcus granulosus, Germinative cells, Zataria multiflora, Essential oil

\section{Background}

Cystic echinococcosis (CE), a neglected zoonotic infection with a significant socioeconomic and health consequences, is caused by the larval stage of Echinococcus granulosus (s.l.) [1]. The parasite life cycle includes dogs and other canids as definitive hosts, while domestic

*Correspondence: moazeni@shirazu.ac.ir

${ }^{1}$ Division of Parasitology, Department of Pathobiology, School of Veterinary Medicine, Shiraz University, Shiraz 71345-1731, Iran

Full list of author information is available at the end of the article ruminants and humans act as intermediate hosts for the parasite [2]. Infected dogs disseminate the parasite's eggs into the environment through their feces. Intermediate hosts become infected by ingesting the fertile eggs. Hexacanth embryos are liberated in the small intestine of these hosts, reach the liver and other organs via the blood circulation and develop to the larval form of the parasite (CE cysts). The dogs become infected by eating the infected organs of intermediate hosts [3]. In humans, even though the infection may be clinically silent, it may 
be severe; in rare cases, it may present as a fatal disease [4].

Number, size, location and viability status of the cysts, the infected organ as well as the bacterial or fungal infection of the cyst may affect the treatment choice. The disease may be treated by surgery, puncture, aspiration, injection, re-aspiration (PAIR), anti-parasitic treatment or watch and wait for inactive cysts [5, 6]. In inoperable cases, anti-parasitic treatment is the only option $[6,7]$. In humans, albendazole, as the drug of choice for anti-parasitic treatment of CE [2], should be administered for long periods and at high doses [8]; therefore, it may be accompanied by adverse side effects in the patients [9]. On the other hand, 2 years after the start of treatment, $40 \%$ of the cysts may be still in the active status [10]. Hence, generally no complete recovery occurs after treatment with albendazole [5]. Therefore, novel and more efficient compounds are urgently required for medical treatment of CE [11-13].

In addition to the need to evaluate the drug/vaccine efficiency, research on the different aspects of $\mathrm{CE}$ is required to study the biological and immunological behavior of the parasite and assess the diagnostic tools for the early detection of the infection in intermediate hosts, particularly in human beings $[14,15]$.

The larval form of E. granulosus (s.l.) is a fluid-filled sac consisting of an inner nucleated or germinal layer and an acellular, tough and elastic laminated layer. The cyst is surrounded externally by a host-produced adventitial layer [16]. Reproducing cells of cyst's germinal layer can be applied to establish an in vitro cell culture system [17]. As a matter of fact, the germinal layer of the cyst acts as a generous and productive source for the other parts of the cyst including the laminated layer, brood capsules and protoscoleces. Hence, the germinative cell cultures can be used for testing anti-echinococcosis agents [18] as well as for other biological studies on CE. The present study aimed (i) to establish a cell culture model in vitro for the germinative cells of the larval stage of E. granulosus (s.l.) and (ii) to evaluate the lethal effect of Zataria multiflora essential oil (ZMEO) on the germinative cells of E. granulosus in vitro.

\section{Methods}

\section{Chemicals}

Medium 199 was purchased from Gibco (Brazil). Fetal bovine serum (FBS), sodium pyruvate, penicillin, streptomycin and amphotericin B were obtained from SigmaAldrich Co. (Germany). Glucose, L-cysteine, L-glutamine, and 2-mercaptoethanol were purchased from Merck Co. (Germany). ZMEO was obtained from Barij Essence Pharmaceutical Co. (Kashan, Iran). Ten-centimeter cell culture Petri dishes and 12-well plates were purchased from Alian Tajhiz Co. (Shiraz, Iran). All other reagents were of analytical grade.

\section{Collection of CE cysts}

Liver and lungs of livestock infected with CE cysts were aseptically collected from Shiraz (southern Iran) industrial slaughterhouses and transferred to the parasitology laboratory of the School of Veterinary Medicine, Shiraz University, under cold and sterile conditions.

\section{Isolation of germinative cells}

In the laboratory, the liver and lungs containing the cysts were first thoroughly washed with tap water. Then, the cyst surfaces were dried with sterile cotton and gauze and sterilized with $70 \%$ ethanol. Subsequently, the fluid of the cysts was aseptically aspirated by sterile syringes. The cyst walls were cut open using a scalpel, and the germinal layer of each cyst was carefully separated from the laminated layer. Germinal layers were washed three times with $40 \mathrm{ml}$ PBS containing $1 \mathrm{ml}$ antibiotics $(10,000 \mu / \mathrm{ml}$ penicillin and $10 \mathrm{mg} / \mathrm{ml}$ streptomycin). Then, the inner surface of the layer was scraped gently by a scraper, and the obtained material was treated with 10 vol. $0.25 \%$ trypsin at room temperature for 15 min with continuous shaking ( 22 cycles/min). Subsequently, the obtained solution was transferred into a sterile glass tube and centrifuged at $715 \times g$ at $4{ }^{\circ} \mathrm{C}$ for $10 \mathrm{~min}$. After discarding the supernatant, the single cell mass remained sedimented at the bottom of the tube. Finally, the cells were counted using a Neubauer chamber before cultivation.

\section{Preparation of culture medium}

The culture medium was prepared based on the study of Albani et al. [19]. Medium 199 was used as the basic culture medium. This medium was supplemented with $10 \%$ fetal bovine serum (FBS), cyst fluid (10\%), reducing agents including 2-mercaptoethanol $\left(5 \times 10^{-5}\right)$, L-cysteine $(100 \mu \mathrm{M})$ and L-glutamine $(2 \mathrm{mM})$, glucose $(4 \mathrm{mg} / \mathrm{ml})$, sodium pyruvate $(1 \mathrm{mM})$, amphotericin $\mathrm{B}(0.5 \mu \mathrm{l} / \mathrm{ml})$ and $100 \mu \mathrm{g} / \mathrm{ml}$ each of penicillin and streptomycin antibiotics. Finally, the $\mathrm{pH}$ of the obtained medium was adjusted to 7.5. These supplements were carefully and cautiously added to $250 \mathrm{ml}$ medium 199 inside a laboratory hood and under sterile conditions. The medium was filtered using a syringe filter with $0.22-\mu \mathrm{m}$ pore size. Finally, the prepared medium was stored in 50-ml Falcon tubes at $4{ }^{\circ} \mathrm{C}$ until use.

\section{In vitro culture of germinative cells}

The cells were cultured based on the study of Albani et al. [19] with some modifications. Ten-centimeter cell culture Petri dishes and 12-well plates were used as the culture vessels. Ten-centimeter cell culture Petri dishes 
were filled with $8 \mathrm{ml}$ culture media, and the wells of 12 -well plates were filled with $2 \mathrm{ml}$ of the medium. The cells were cultured with a concentration of $10^{4}$ cells $/ \mathrm{ml}$ culture medium. Amphotericin B ( $50 \mu \mathrm{l} / 100 \mathrm{ml}$ of culture medium) was added to prevent fungal growth in the culture media. The culture vessels were incubated at $37^{\circ} \mathrm{C}$ in an incubator without $\mathrm{CO}_{2}$ and in aerobic conditions. The culture medium was replaced every 7 days. Cell cultures were monitored periodically (every 10 days), and photography was performed using an inverted microscope.

\section{Cell passaging}

Two months after the start of cultivation, the attached cells were passaged. In the first step, the culture medium was completely removed, and then the attached cells were washed gently with PBS (2 times). Subsequently, after discarding the used PBS, the attached cells were resuspended in $25 \%$ trypsin-containing EDTA $(2 \mathrm{mg} / \mathrm{ml})$. Enough solution was added to cover the bottom of the culture plates $(1.5 \mathrm{ml})$. After $15 \mathrm{~min}$ incubation at $37^{\circ} \mathrm{C}$, the culture media containing FBS were added to neutralize the trypsin effect. After pipetting, the resuspended cells were transferred to a Falcon tube and centrifuged at $180 \times g$ for $5 \mathrm{~min}$. Then, the medium was discarded and fresh medium was added. After pipetting, the cell suspension was transferred into the new culture plates. In this study, the cells were passaged four times with 2-month intervals.

\section{GC and GC-MS analysis of ZMEO}

The chemical composition of ZMEO was determined using a gas chromatography (GC model 7890)-mass spectrometry (MS model 5975) system (Agilent Technologies, USA). The analysis was performed using a HP-5 fusedsilica column with $30 \mathrm{~m}$ length, $0.25 \mathrm{~mm}$ diameter and $0.25 \mu \mathrm{m}$ film thickness. The oven temperature was set to rise from 60 to $210^{\circ} \mathrm{C}$ at a rate of $3^{\circ} \mathrm{C} / \mathrm{min}$ and then was increased to $240{ }^{\circ} \mathrm{C}$ at a rate of $20^{\circ} \mathrm{C} / \mathrm{min}$. The final temperature was held for $8.5 \mathrm{~min}$. Both the transfer line and injector temperatures were kept at $280^{\circ} \mathrm{C}$. Helium was used as the carrier at a flow rate of $1 \mathrm{ml} / \mathrm{mi}$. The electron ionization energy of MS was $70 \mathrm{eV}$. The constituents of the oil were identified by comparing their retention indices with those reported in the Wiley GC-MS Library and Adams Library [20].

\section{In vitro lethal effect of ZMEO on germinative cells}

ZMEO was used at concentrations of $0.5,1,2,3,4,5$, 6,7 and $8 \mathrm{mg} / \mathrm{ml}$. For better solubility of ZMEO in the culture medium, twice as much Tween 80 was added as ZMEO (v/v). The cultured cells were treated with different concentrations of ZMEO at different times. In initial evaluations, lower concentrations of the oil were applied for 12, 24 and $48 \mathrm{~h}$. Accordingly, higher concentrations were applied for shorter times. All the experiments were performed in triplicate, except for $0.5,1$ and $5 \mathrm{mg} / \mathrm{ml}$, which were carried out in duplicate. Albendazole at a concentration of $20 \mathrm{mg} / \mathrm{ml}$ for $120 \mathrm{~min}$ was used as positive control.

\section{Viability test}

Viability of cells was assessed by trypan blue exclusion assay. Germinative cell suspension $(0.1 \mathrm{ml})$ and $0.25 \%$ trypan blue stain $(0.1 \mathrm{ml})$ were placed in a well of a 96-well plate. After gently pipetting, the plate was incubated at room temperature for $5 \mathrm{~min}$. Subsequently, the viable (uncolored) and dead (blue colored) cells were counted using a Neubauer chamber. The number of cells counted in each experiment ranged from 265,000 to 540,000 (average 41,200 cells).

\section{Statistical analysis}

The results of the lethal effect of ZMEO on the cultured cells, are presented as mean \pm standard deviation. Statistical analysis was performed using SPSS software, version 22 . The data were analyzed by Mann-Whitney $U$ test. $P<0.05$ was considered statistically significant.

\section{Results}

Eighteen hours after the start of cultivation, the cells attached to the bottom of the plate and began to divide via binary division. The cells were round in shape and variable in size with an average diameter of approximately $2-4 \mu \mathrm{m}$. A gradual increase in the dividing cells was observed at 7 and 15 days after the start of cultivation (Fig. 1a, b), and a significant increase in the cell number was evident at 20,30 and 45 days after incubation (Fig. 1c-e) so that at 45 days of cultivation the number of cells increased to $5 \times 10^{4}$ cells $/ \mathrm{ml}$ culture medium. However, at 60 days of incubation the number of cells had decreased and aggregation behavior was noticeable (Fig. 1f).

After passaging, the cells continue their growth, and gradual division and proliferation of the cells were evident over the time period of 1 to 60 days of incubation. Even though the cell growth was slow till 30 days, it was much higher between 30 and 60 days of incubation. However, the cultured cells in two plates remained viable for nearly 10 months, without any passaging (Fig. 2).

The chemical compositions of ZMEO identified by GC-MS analysis are shown in Table 1. A total of $52 \mathrm{com}-$ pounds were identified, among which carvacrol (56.95\%), p-cymene $(7.49 \%)$, g-terpinene $(7.12 \%)$, thymol $(4.60 \%)$, a-pinene (3.58\%) and carvacrol methyl ether (3.03\%) were the major components. 

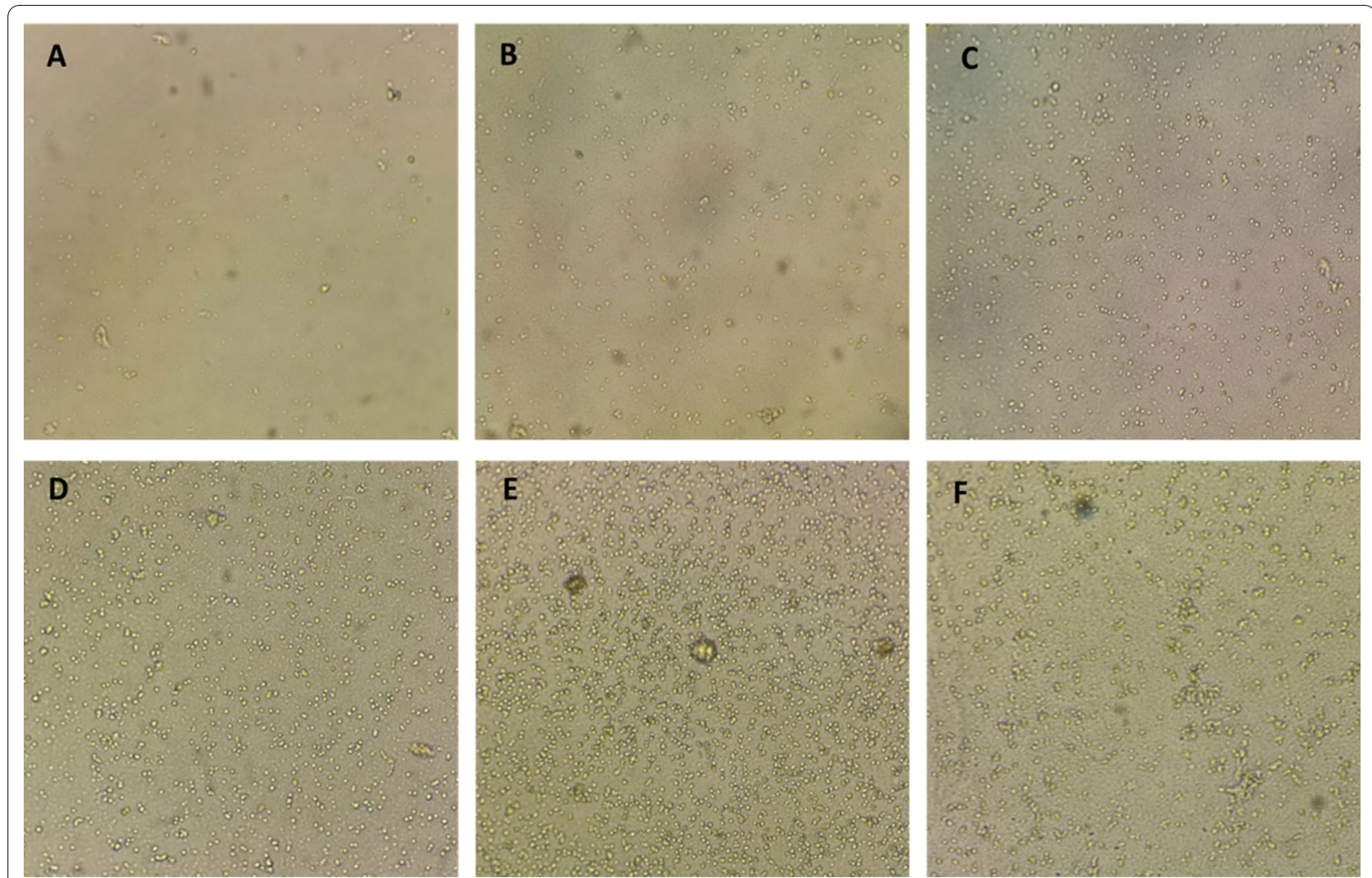

Fig. 1 Inverted microscopy of Echinococcus granulosus germinative cell cultures at 7 (a), 14 (b), 20 (c), 30 (d) and 45 (e) days of cultivation. Note the aggregation behavior of the cells and initial monolayer formation at 60 days of culture (f)

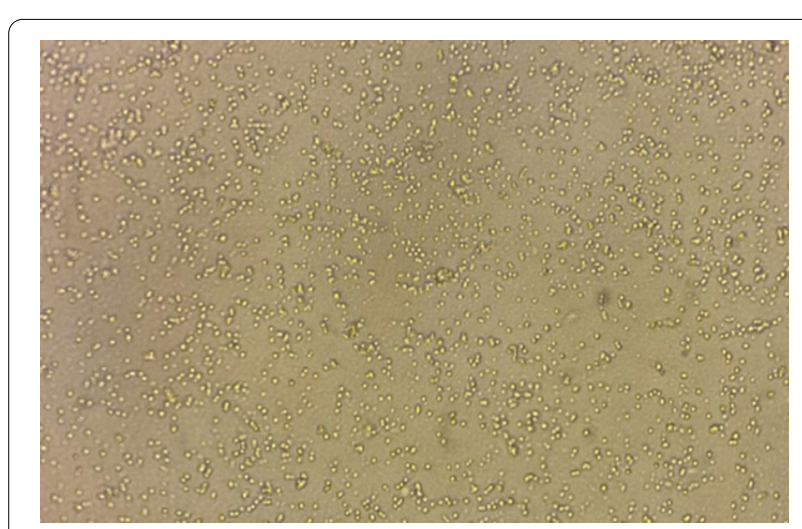

Fig. 2 Inverted microscopy of Echinococcus granulosus germinative cell cultures, 10 months after plating

The results of the in vitro lethal effect of ZMEO on the cultured germinative cells of E. granulosus are summarized in Table 2. As shown in this table, ZMEO with concentrations of 0.5 and $1 \mathrm{mg} / \mathrm{ml}$ (after $48 \mathrm{~h}$ ), $2 \mathrm{mg} /$ $\mathrm{ml}$ (after $12 \mathrm{~h}$ ), $3 \mathrm{mg} / \mathrm{ml}$ (after $3 \mathrm{~h}$ ) and 5 and $6 \mathrm{mg} / \mathrm{ml}$ (after $30 \mathrm{~min}$ ) showed no lethal effect on the cultured germinative cells of E. granulosus. However, when used for a longer time or with higher concentrations, the lethality of the oil increased gradually. When the cells were treated with $3 \mathrm{mg} / \mathrm{ml} \mathrm{ZMEO}$, its lethal effect on the cells was 29 and $100 \%$ after 6 and $12 \mathrm{~h}$, respectively. The lethal effect of $4 \mathrm{mg} / \mathrm{ml} \mathrm{ZMEO}$ on the cells was $51 \%$ and $100 \%$ after 2 and $3 \mathrm{~h}$, respectively. ZMEO at concentrations of 5 and $6 \mathrm{mg} / \mathrm{ml}$ killed all the cells after $1 \mathrm{~h}$. However, $7 \mathrm{mg} / \mathrm{ml} \mathrm{ZMEO} \mathrm{killed} 45 \%$ and 100 of cells after 15 and 25 min, respectively. When the oil was used at $8 \mathrm{mg} / \mathrm{ml}$ concentration, its lethal effect was $46 \%$ and $100 \%$ only after 5 and $7 \mathrm{~min}$, respectively. The obtained results evidently showed that the lethal effect of ZMEO on the germinative cells of E. granulosus was concentration and time dependent. Statistical analysis revealed a significant lethality of ZMEO on the cultured cells at concentrations of $2 \mathrm{mg} / \mathrm{ml}$ (after $24 \mathrm{~h}$ ), $3 \mathrm{mg} / \mathrm{ml}$ (after $6 \mathrm{~h}$ ), $4 \mathrm{mg} / \mathrm{ml}$ (after $2 \mathrm{~h}$ ), 5 and $6 \mathrm{mg} /$ $\mathrm{ml}$ (after $60 \mathrm{~min}$ ), $7 \mathrm{mg} / \mathrm{ml}$ (after $25 \mathrm{~min}$ ) and $8 \mathrm{mg} /$ $\mathrm{ml}$ (after $5 \mathrm{~min})(P<0.05)$. The lethal effect of ZMEO was significantly higher than that of the positive control (albendazole) $(P<0.05)$ when the oil was applied at 
Table 1 Chemical composition of Zataria multiflora essential oil identified by gas chromatography-mass spectroscopy

\begin{tabular}{|c|c|c|c|c|c|c|c|}
\hline No. & Component & $\%$ & $\mathrm{Rl}$ & No. & Component & $\%$ & $\mathrm{RI}$ \\
\hline 1 & Tricyclene & 0.012 & 922.1 & 27 & a-Terpineol & 0.458 & 1190 \\
\hline 2 & a-Thujene & 0.585 & 925.4 & 28 & trans-Dihydro carvone & 0.078 & 1203 \\
\hline 3 & a-Pinene & 3.583 & 930.9 & 29 & Thymol methyl ether & 0.063 & 1233 \\
\hline 4 & Camphene & 0.189 & 951.1 & 30 & Carvacrol methyl ether & 3.029 & 1243 \\
\hline 5 & Thuja-2,4(10)-diene & 0.009 & 956.6 & 31 & Unknown & 0.058 & 1254 \\
\hline 6 & Sabinene & 0.011 & 972.4 & 32 & p-Anisaldehyde dimethyl acetal & 0.087 & 1256 \\
\hline 7 & b-Pinene & 0.745 & 976.1 & 33 & (E)-Anethole & 0.179 & 1284 \\
\hline 8 & 3-Octanone & 0.249 & 984.9 & 34 & Thymol & 4.601 & 1290 \\
\hline 9 & Myrcene & 1.524 & 990.4 & 35 & Carvacrol & 56.951 & 1299 \\
\hline 10 & 3-Octanol & 0.277 & 994.4 & 36 & Thymol acetate & 0.109 & 1354 \\
\hline 11 & a-Phellandrene & 0.258 & 1001 & 37 & Eugenol & 0.056 & 1357 \\
\hline 12 & p-Mentha-1(7),8-iene & 0.073 & 1004 & 38 & Carvacrol acetate & 1.984 & 1373 \\
\hline 13 & a-Terpinene & 1.817 & 1016 & 39 & (E)-Caryophyllene & 1.958 & 1418 \\
\hline 14 & p-Cymene & 7.497 & 1025 & 40 & Unknown & 0.069 & 1426 \\
\hline 15 & Limonene & 0.627 & 1028 & 41 & b-Copaene & 0.066 & 1432 \\
\hline 16 & 1,8-Cineole & 0.223 & 1030 & 42 & Aromadendrene & 0.624 & 1437 \\
\hline 17 & (Z)-b-Ocimene & 0.02 & 1036 & 43 & Unknown & 0.095 & 1441 \\
\hline 18 & (E)-b-Ocimene & 0.061 & 1046 & 44 & a-Humulene & 0.15 & 1451 \\
\hline 19 & g-Terpinene & 7.127 & 1059 & 45 & allo-Aromadendrene & 0.134 & 1458 \\
\hline 20 & cis-Sabinene hydrate & 0.05 & 1066 & 46 & b-Selinene & 0.069 & 1486 \\
\hline 21 & Terpinolene & 0.311 & 1088 & 47 & d-Selinene & 0.059 & 1489 \\
\hline 22 & Linalool & 1.104 & 1098 & 48 & Viridiflorene & 0.718 & 1493 \\
\hline 23 & 1-Octen-3-yl acetate & 0.073 & 1111 & 49 & b-Bisabolene & 0.043 & 1507 \\
\hline 24 & 3-Octanol acetate & 0.033 & 1123 & 50 & $\mathrm{~d}$-Cadinene & 0.03 & 1522 \\
\hline 25 & Borneol & 0.16 & 1164 & 51 & Spathulenol & 0.356 & 1575 \\
\hline 26 & Terpinen-4-ol & 1.035 & 1176 & 52 & Caryophyllene oxide & 0.317 & 1581 \\
\hline
\end{tabular}

$R /$ retention index

concentrations of 5 and $6 \mathrm{mg} / \mathrm{ml}$ (after $60 \mathrm{~min}), 7 \mathrm{mg} /$ $\mathrm{ml}$ (after $25 \mathrm{~min}$ ) and $8 \mathrm{mg} / \mathrm{ml}$ (after $5 \mathrm{~min}$ ) (Table 2).

\section{Discussion}

Echinococcus granulosus (s.l.) is the causative agent for $\mathrm{CE}$, which is an important disease; hence, study on various features of this parasite such as its biology, pathogenesis, diagnosis and treatment is important [14]. There are two alternative tools for the study on the larval form of $E$. granulosus: the culture of parasite in the laboratory and establishment of the infection in laboratory animals [15]. However, in vivo experiments are costly, time consuming and ethically problematic [21].

Many attempts have been made to establish cell cultures from nematodes [22, 23], trematodes [24] and cestodes [17, 25-29]. The wall of the larval form of $E$. granulosus (CE cyst) has two layers: an acellular external laminated layer (made of polysaccharides) and an internal germinal layer consisting of multiplying cells, which may differentiate into protoscoleces or daughter cysts.
Proliferating cells of the germinal layer may be used for in vitro culture [17].

Compared to the vast knowledge available on the morphological features of CE cysts, little information is available on the molecular structure of the germinal layer of the parasite. The germinal layer of CE cysts with high ATPase activity plays a significant role in the growth and survival of the cyst [30]. The germinal layer is joined with the brood capsules' wall as well as with the tegument of the protoscoleces [31]. On the other hand, the germinal layer structure and organization are similar to the tegument of the protoscoleces, the brood capsules' wall and also the tegument of the adult form of the parasite [32].

According to the critical role of the germinal layer in the growth and survival of the cyst, it is wise to evaluate the effect of anti-echinococcal agents on the germinative cells of this layer. Hence, availability of $E$. granulosus germinative cells is quite relevant for development of more effective anti-CE drugs [18].

In the present study, we attempted to evaluate the lethal effect of ZMEO directly on the germinative cells 
Table 2 Lethal effect of Z. multiflora essential oil (ZMEO) with different concentrations and at different exposure times on the cultured germinative cells of Echinococcus granulosus

\begin{tabular}{|c|c|c|c|c|c|}
\hline \multirow[t]{2}{*}{ Cons (mg/ml) } & \multicolumn{5}{|c|}{ Lethal effect on the cultured cells (mean \pm SD) $(\%)^{*}$} \\
\hline & Time & ZMEO & Tween $80^{* *}$ & Albendazole (20 mg/ml) & Negative control \\
\hline \multirow[t]{3}{*}{0.5} & $12 \mathrm{~h}$ & $0.00^{\mathrm{a}}$ & $0.00^{\mathrm{a}}$ & - & $0.00^{\mathrm{a}}$ \\
\hline & $24 \mathrm{~h}$ & $0.00^{\mathrm{a}}$ & $0.00^{\mathrm{a}}$ & - & $0.00^{\mathrm{a}}$ \\
\hline & $48 \mathrm{~h}$ & $0.00^{\mathrm{a}}$ & $0.00^{\mathrm{a}}$ & - & $0.00^{\mathrm{a}}$ \\
\hline \multirow[t]{3}{*}{1} & $12 \mathrm{~h}$ & $0.00^{\mathrm{a}}$ & $0.00^{\mathrm{a}}$ & - & $0.00^{\mathrm{a}}$ \\
\hline & $24 \mathrm{~h}$ & $0.00^{\mathrm{a}}$ & $0.00^{\mathrm{a}}$ & - & $0.00^{\mathrm{a}}$ \\
\hline & $48 \mathrm{~h}$ & $0.00^{\mathrm{a}}$ & $0.00^{\mathrm{a}}$ & - & $0.00^{\mathrm{a}}$ \\
\hline \multirow[t]{3}{*}{2} & $12 \mathrm{~h}$ & $0.00^{\mathrm{a}}$ & $0.00^{\mathrm{a}}$ & - & $0.00^{\mathrm{a}}$ \\
\hline & $24 \mathrm{~h}$ & $20.05 \pm 1.86^{\mathrm{a}}$ & $0.00^{\mathrm{b}}$ & - & $0.00^{b}$ \\
\hline & $48 \mathrm{~h}$ & $40.32 \pm 2.11^{\mathrm{a}}$ & $0.00^{b}$ & - & $0.00^{b}$ \\
\hline \multirow[t]{3}{*}{3} & $3 \mathrm{~h}$ & $0.00^{\mathrm{a}}$ & $0.00^{\mathrm{a}}$ & - & $0.00^{\mathrm{a}}$ \\
\hline & $6 \mathrm{~h}$ & $29.10 \pm 3.63^{\mathrm{a}}$ & $0.00^{b}$ & - & $0.00^{b}$ \\
\hline & $12 \mathrm{~h}$ & $100 \pm 0.00^{\mathrm{a}}$ & $0.00^{b}$ & - & $0.00^{b}$ \\
\hline \multirow[t]{2}{*}{4} & $2 \mathrm{~h}$ & $51.75 \pm 4.47^{a}$ & $0.00^{b}$ & $0.00^{b}$ & $0.00^{b}$ \\
\hline & $3 \mathrm{~h}$ & $100 \pm 0.00^{\mathrm{a}}$ & $0.00^{b}$ & - & $0.00^{b}$ \\
\hline \multirow[t]{2}{*}{5} & $30 \mathrm{~min}$ & $0.00^{\mathrm{a}}$ & $0.00^{\mathrm{a}}$ & $0.00^{\mathrm{a}}$ & $0.00^{\mathrm{a}}$ \\
\hline & $60 \mathrm{~min}$ & $100 \pm 0.00^{\mathrm{a}}$ & $0.00^{b}$ & $0.00^{\mathrm{b}}$ & $0.00^{b}$ \\
\hline \multirow[t]{2}{*}{6} & $30 \mathrm{~min}$ & $0.00^{\mathrm{a}}$ & $0.00^{\mathrm{a}}$ & $0.00^{\mathrm{a}}$ & $0.00^{\mathrm{a}}$ \\
\hline & $60 \mathrm{~min}$ & $100 \pm 0.00^{\mathrm{a}}$ & $0.00^{\mathrm{b}}$ & $0.00^{\mathrm{b}}$ & $0.00^{b}$ \\
\hline \multirow[t]{2}{*}{7} & $15 \mathrm{~min}$ & $45.90 \pm 3.00^{\mathrm{a}}$ & $0.00^{b}$ & $0.00^{\mathrm{b}}$ & $0.00^{b}$ \\
\hline & $25 \mathrm{~min}$ & $100 \pm 0.00^{\mathrm{a}}$ & $0.00^{b}$ & $0.00^{\mathrm{b}}$ & $0.00^{b}$ \\
\hline \multirow[t]{2}{*}{8} & $5 \mathrm{~min}$ & $46.33 \pm 3.79^{a}$ & $0.00^{b}$ & $0.00^{\mathrm{b}}$ & $0.00^{b}$ \\
\hline & $7 \mathrm{~min}$ & $100 \pm 0.00^{\mathrm{a}}$ & $0.00^{b}$ & $0.00^{\mathrm{b}}$ & $0.00^{b}$ \\
\hline
\end{tabular}

ZMEO: Zataria multiflora essential oil, Cons: concentrations, h: hour, min: minutes *Different letters show significant difference in each row

**Tween 80 was used at twice the concentration of ZMEO

of E. granulosus. The primary need for this study was the accessibility of the live cultured germinative cells of the parasite. That is why we first tried to establish the required cell cultures for our experiments.

Several attempts have been to establish primary cell cultures from the germinative cells of E. granulosus [19]. The complexity of the E. granulosus biological cycle, difficulty in production of appropriate in vitro culture conditions and inadequate cell isolation methods may be considered the main factors related to failure in establishing primary cell cultures from E. granulosus germinative cells [29]. However, our efforts in cultivation of E. granulosus germinative cells were successful. Even though the cells' growth was slow for several days after the start of cultivation, almost 3 weeks later, the number of cells was considerable, and 45 days after the start of cultivation, the cell concentration was suitable for the desired experiments $\left(5 \times 10^{4}\right.$ cells $\left./ \mathrm{ml}\right)$.

We observed many cells while they had the dividing status. Proliferating E. granulosus germinative cells with high protein synthesis potential and high proliferating activity differentiate into protoscoleces of the hydatid cyst [33]. These cells are also capable of producing new cysts [19]. In the current study, the inner surface of germinal layers was scraped gently by a scraper, and the obtained pellets were trypsinized for cell isolation. As previously reported by Albani et al. [19], we also obtained cultures with no contamination with host cells.

Albani et al. [19] succeeded in maintaining the isolated cells of the germinal layer of CE cysts in vitro for at least 4 months. They stated that "The cells grew for over 10 passages without morphological or biochemical changes." In the present study, the cells remained alive for at least 60 days, which was enough for in vitro evaluation of the lethal effect of ZMEO. In addition, the results of cell passaging were also satisfactory. The cells were passaged four times with 60-day intervals, and they were still alive and dividing after the fourth passage. However, in the current study, the cells of two culture plates remained viable for nearly 10 months without any passaging. This may be attributed to the high proliferative potential of E. granulosus germinative cells. 
The present study was done to evaluate the lethal effect of ZMEO on the germinative cells of E. granulosus. Luckily, the results were hopeful. Antidiabetic, anti-aphthous, anti-nociceptive, anti-inflammatory, antiprotozoal, antimicrobial and antifungal activities of ZMEO have been previously documented [34]. In vitro high scolicidal activity has been previously reported for the methanolic extract [35] and aromatic water of Z. multiflora [36]. In addition, anti-hydatid properties of the methanolic extract [37], aromatic water [38] and essential oil [39-42] of Z. multiflora have been reported in earlier in vivo studies.

In the present study, the lethal effect of ZMEO on the germinative cells of E. granulosus at concentrations of $3,4,5$ and $6 \mathrm{mg} / \mathrm{ml}$ was $100 \%$ after $12,3,1$ and $1 \mathrm{~h}$ of exposure, respectively. The lethal efficacy of the oil was much higher at concentrations of 7 and $8 \mathrm{mg} / \mathrm{ml}$, which means that ZMEO killed all the cells with these concentrations after only 25 and $7 \mathrm{~min}$, respectively. To the best of our knowledge, this is the first report that describes the lethal effect of ZMEO on the germinative cells of E. granulosus.

Benzimidazoles, as the most familiar therapeutic drugs for $\mathrm{CE}$, only have a static effect on the parasite; therefore, complete cure may not be achieved after administration of albendazole, even with high doses and for long periods of time [43]. On the other hand, long-term albendazole therapy with high doses may be accompanied by adverse effects in treated patients [2, $4,44,45]$. The dynamic nature and complexity of CE make its treatment problematic [46]. Many efforts are being made to introduce novel therapeutic agents for treatment of the disease worldwide.

In accordance with our study, in previous chemical analysis by GC and GC-MC, thymol and carvacrol have been found to be the main components of ZMEO [34, 40, 47, 48]; interestingly, both have scolicidal power and anti-CE properties [49-51].

Both thymol and carvacrol, as the lipophilic compounds, could simply enter the cell membranes, altering their permeability and causing the release of cellular contents [34]. This property may elucidate the lethal effect of ZMEO on germinative E. granulosus cells. In earlier studies, the antioxidant, hepatoprotective and immunostimulatory activities of ZMEO have been documented $[34,52]$. Previous studies also confirmed that thymol and carvacrol as the main components of ZMEO are safe compounds [53].

Regarding the above issues, the lethal effect of ZMEO on the germinative cells of E. granulosus might be considered an encouraging step forward in the medical treatment of CE using an herbal product.

\section{Conclusions}

Forty-five days after the start of cultivation, the germinative cell concentration was suitable for evaluation of the in vitro lethal effect of ZMEO on the cultured cells. ZMEO at concentrations of 7 and $8 \mathrm{mg} / \mathrm{ml}$ killed all the cells after only 25 and $7 \mathrm{~min}$, respectively. The results of this study revealed that the oil effect on the cells was concentration and time dependent. These findings provide an opportunity for introduction of a novel, more effective and safer therapeutic agent for treatment of CE. However, further studies are required in laboratory animals before recommendation of this treatment modality in humans.

\section{Abbreviations}

CE: Cystic echinococcosis; ZMEO: Zataria multiflora essential oil; GC-MS: Gas chromatography-mass spectrometry; PAIR: Puncture, aspiration, injection, re-aspiration; FBS: Fetal bovine serum; PBS: Phosphate-buffered saline; EDTA: Ethylenediaminetetraacetic acid.

\section{Acknowledgements}

We thank Mr. Amir Motabi Alavi for his kind technical assistance during the course of this study.

\section{Authors' contributions}

NK: performing the experiments, collection of the data, writing the first draft of manuscript. MM: conceptualization and designing the study, performing the experiments, revising and editing the final version of the manuscript. AM: performing the experiments, reviewing and editing the manuscript. All authors read and approved the final manuscript.

\section{Funding}

This work was financially supported by Shiraz University (grant no.

97GCU2M1346). The funder had no role in the study design, data collection, decision to publish or preparation of the manuscript process.

Availability of data and materials

All relevant data are within the main paper.

\section{Declarations}

Ethics approval and consent to participate

Not applicable.

\section{Consent for publication}

Not applicable.

\section{Competing interests}

The authors declare that they have no competing interests.

\section{Author details}

${ }^{1}$ Division of Parasitology, Department of Pathobiology, School of Veterinary Medicine, Shiraz University, Shiraz 71345-1731, Iran. ${ }^{2}$ Division of Virology,

Department of Pathobiology, School of Veterinary Medicine, Shiraz University, Shiraz, Iran.

Received: 26 December 2020 Accepted: 3 May 2021

Published online: 17 May 2021

References

1. Tamarozzi F, Akhan O, Cretu CM, Vutova K, Fabiani M, Orsten S, et al. Epidemiological factors associated with human cystic echinococcosis: a 
semi-structured questionnaire from a large population-based ultrasound cross-sectional study in eastern Europe and Turkey. Parasites Vectors. 2019:12:371.

2. Moro P, Schantz PM. Echinococcosis: a review. Int J Infect Dis. 2009;13:125-33.

3. Larrieu E, Costa MT, Cantoni G, Alvarez R, Cavagion L, Labanchi JL, et al. Ovine Echinococcus granulosus transmission dynamics in the province of Rio Negro, Argentina, 1980-1999. Vet Parasitol. 2001;98:263-72.

4. Li T, Ito A, Pengcuo R, Sako Y, Chen X, Qiu D, et al. Post-treatment followup study of abdominal cystic echinococcosis in Tibetan communities of northwest Sichuan Province, China. PLoS Negl Trop Dis. 2011;5:e1364.

5. Pensel PE, Elissondo N, Gambino G, Gamboa GU, Benoit JP, Elissondo MC. Experimental cystic echinococcosis therapy: in vitro and in vivo combined 5-fluorouracil/albendazole treatment. Vet Parasitol. 2017;245:62-70.

6. Vuitton DA, McManus DP, Rogan MT, Romig T, Gottstein B, Naidich A, et al. International consensus on terminology to be used in the field of echinococcoses. Parasite. 2020;27:41.

7. Hemphill A, Müller J. Alveolar and cystic echinococcosis: towards novel chemotherapeutical treatment options. J Helminthol. 2009;83:99-111.

8. Walker M, Rossignol JF, Torgerson P, Hemphill A. In vitro effects of nitazoxanide on Echinococcus granulosus protoscoleces and metacestodes. J Antimicrob Chemother. 2004;54:609-16.

9. Kang BS, Choi JS, Lee SE, Lee JK, Kim TH, Jang WS, et al. Enhancing the in vitro anticancer activity of albendazole incorporatedinto chitosancoated PLGA nanoparticles. Carbohydr Polym. 2017;159:39-47.

10. Stojkovic M, Zwahlen M, Teggi A, Vutova K, Cretu CM, Virdone R, et al. Treatment response of cystic echinococcosis to benzimidazoles: a systematic review. PLoS Negl Trop Dis. 2009;3(9):e524.

11. Brunetti E, Praticò L, Neumayr A, Maestri M, Tamarozzi F. Update on treatment for cystic echinococcosis of the liver. Curr Treat Options Infect Dis. 2016:8:153-64.

12. Zhang $S$, Zhou Y, Su L, Zhang $X$, Wang H, Liu B. In vivo evaluation of the efficacy of combined albedazole-IFN-a treatment for cystic echinococcosis in mice. Parasitol Res. 2017;116:735-42.

13. Wen $H$, Vuitton L, Tuxun T, Li J, Vuitton DA, Zhang W, et al. Echinococcosis: advances in the 21st century. Clin Microbiol Rev. 2019;32(2):e00075-e118.

14. Mohammadzadeh T, Sadjjadi SM, Rahimi HR, Shams S. Establishment of a modified in vitro cultivation of protoscoleces to adult Echinococcus granulosus; an important way for new investigations on hydatidosis. Iran J Parasitol. 2012;7:59-66.

15. Ahmadnia S, Moazeni M, Mohammadi-Samani S. Hydatid cyst formation in male Balb/c mice following the intraperitoneal injection of live protoscoleces and activated oncospheres: a comparative study. J Parasit Dis. 2014:38:77-80

16. Albani CM, Cumino AC, Elissondo MC, Denegri GM. Development of a cell line from Echinococcus granulosus germinal layer. Acta Trop. 2014:128:124-9.

17. Fiori PL, Monaco G, Scappaticci S, Pugliese A, Canu N, Cappuccinelli P. Establishment of cell cultures from hydatid cysts of Echinococcus granulosus. Int J Parasitol. 1988;18:297-305.

18. Koziol U, Brehm K. Recent advances in Echinococcus genomics and stem cell research. Vet Parasitol. 2015;213:92-102.

19. Albani CM, Elissondo MC, Cumino AC, Chisari A, Denegri GM. Primary cell culture of Echinococcus granulosus developed from the cystic germinal layer: biological and functional haracterization. Int J Parasitol. 2010;40:1269-75.

20. Adams RP. Identification of essential oil components by gas chromatography/mass spectrometry. 4th ed. Carol Stream: Allured Publishing; 2007.

21. Berean KJ, Adetutu EM, Ou JZ, Nour M, Nguyen EP, Paull D, et al. A unique in vivo approach for investigating antimicrobial materials utilizing fistulated animals. Sci Rep. 2015;5:11515.

22. Coyne CP, Brake D. Characterization of Haemonchus contortus derived cell populations propagated in vitro in a tissue culture environment and their potential to induce protective immunity in sheep. Int J Parasitol. 2001;31:359-76.

23. Strange K, Christensen M, Morrison R. Primary culture of Caenorhabditis elegans developing embryo cells for electrophysiological, cell biological and molecular studies. Nat Protoc. 2007;2:1003-12.

24. Coustau CP, Yoshino TP. Flukes without snails: advances in the in vitro cultivation of intramolluscan stages of trematodes. Exp Parasitol. 2000;94:62-6.
25. Furuya K. An established cell line of larval Echinococcus mutilocularis. Int J Parasitol. 1991;21:233-40.

26. Toledo A, Cruz C, Fragoso G, Laclette JP, Merchant MT, Hernandez M, et al. In vitro culture of Taenia crassiceps larval cells and cyst regeneration after injection into mice. J Parasitol. 1997:83:189-93.

27. Hemphill A, Stettler M, Walker M, Siles-Lucas M, Fink R, Gottstein B. Culture of Echinococcus multilocularis metacestodes: an alternative to animal use. Trends Parasitol. 2002;18:445-51.

28. Spiliotis M, Tappe D, Sesterhenn L, Brehm K. Long-term in vitro cultivation of Echinococcus multilocularis metacestodes under axenic conditions. Parasitol Res. 2004;92:430-2.

29. Spiliotis M, Lechner S, Tappe D, Scheller C, Krohne G, Brehm K. Transient transfection of Echinococcus multilocularis primary cells and complete in vitro regeneration of metacestode vesicles. Int J Parasitol. 2008;38:1025-39.

30. Del Cacho E, Causape C, Sanchez-Acedo C, Quilez J. Cytochemical study of the germinal membrane of the Echinococcus granulosus cyst. Vet Parasitol. 1996;62:101-6.

31. Morseth DJ. Fine structure of the hydatid cyst and protoscolex of Echinococcus granulosus. J Parasitol. 1967;53:312-25.

32. Bortoletti G, Ferretti G. Ultrastructural aspects of fertile and sterile cysts of Echinococcus granulosus developed in hosts of different species. Int J Parasitol. 1978;8:421-31.

33. Galindo M, Paredes R, Marchant C, Mino V, Galanti N. Regionalization of DNA and protein synthesis in developing stages of the parasitic platyhelminth Echinococcus granulosus. J Cell Biochem. 2003;90:294-303.

34. Sajed H, Sahebkar A, Iranshahi M. Zataria multiflora Boiss. (Shirazi thyme) —an ancient condiment with modern pharmaceutical uses. J Ethnopharmacol. 2013;145:686-95.

35. Moazeni M, Roozitalab A. High scolicidal effect of Zataria multiflora on protoccoleces of hydatid cyst: an in vitro study. Comp Clin Pathol. 2012;21:99-104.

36. Moazeni M, Larki S, Pirmoradi G, Rahdar M. Scolicidal effect of the aromatic water of Zataria multiflora: an in vitro study. Comp Clin Pathol. 2015;24:1057-62.

37. Moazeni M, Larki S, Saharkhiz MJ, Oryan A, Lari MA, Alavi AM. In vivo study of the efficacy of the aromatic water of Zataria multiflora on hydatid cysts. Antimicrob Agents Chemother. 2014;58:6003-8.

38. Moazeni M, Larki S, Oryan A, Saharkhiz MJ. Preventive and therapeutic effects of Zataria multiflora methanolic extract on hydatid cyst: an in vivo study. Vet Parasitol. 2014;205:107-12.

39. Kavoosi G, Purfard AM. Scolicidal effectiveness of essential oil from Zataria multiflora and Ferula assafoetida: disparity between phenolic monoterpenes and disulphide compounds. Comp Clin Pathol. 2013;22:999-1005.

40. Mahmoudvand H, Mirbadie SR, Sadooghian S, Fasihi Harandi M, Jahanbakhsh S, Saedi DE. Chemical composition and scolicidal activity of Zataria multiflora Boiss. essential oil. J Essent Oil Res. 2017;29:42-7.

41. Moazeni M, Borji H, Saboor Darbandi M, Saharkhiz MJ. In vitro and in vivo antihydatid activity of a nano emulsion of Zataria multiflora essential oil. Res Vet Sci. 2017;114:308-12.

42. Yazdi MK, Haniloo A, Ghaffari A, Torabi N. Antiparasitic effects of Zataria multiflora essential oil nano-emulsion on larval stages of Echinococcus granulosus. J Parasit Dis. 2020;44:429-35.

43. Wang W, Li J, Yao J, Wang T, Li S, Zheng X, et al. In vitro and in vivo efficacies of novel carbazole aminoalcohols in the treatment of cystic echinococcosis. J Antimicrob Chemother. 2017;72:3122-30.

44. Manouras A, Genetzakis M, Lagoudianakis EE, Papadima A, Triantafillou C, Kekis PV, Filis K, Katergiannakis V. Intact germinal layer of liver hydatid cysts removed after administration of albendazole. Neth J Med. 2007:63:112-6.

45. Haralabidis S, Diakou A, Frydas S, Papadopoulos E, Mylonas A, Patsias A, Roilides E, Giannoulis E. Long-term evaluation of patients with hydatidosis treated with albendazole and praziquantel. Int J Immunopathol Pharmacol. 2008;21:429-35.

46. Junghanss T, Menezes da Silva A, Horton J, Chiodini PL, Brunetti E. Clinical management of cystic echinococcosis: state of the art, problems, and perspectives. Am J Trop Med Hyg. 2008;79:301-11.

47. Saei-Dehkordi SS, Tajik H, Moradi M, Khalighi-Sigaroodi F. Chemical composition of essential oils in Zataria multiflora Boiss. from different parts of 
Iran and their radical scavenging and antimicrobial activity. Food Chem Toxicol. 2010;48:1562-7.

48. Saedi Dezaki E, Mahmoudvand H, Sharififar F, Fallahi S, Monzote L, Ezatkhah F. Chemical composition along with anti-leishmanial and cytotoxic activity of Zataria multiflora. Pharm Biol. 2016;54:752-8.

49. Elissondo MC, Albani CM, Gende L, Eguaras M, Denegri G. Efficacy of thymol against Echinococcus granulosus protoscoleces. Parasitol Int. 2008:57:185-90.

50. Elissondo MC, Pensel PE, Denegri GM. Could thymol have effectiveness on scolices and germinal layer of hydatid cysts? Acta Trop. 2013:125:251-7.

51. Fabbri J, Maggiore MA, Pensel PE, Denegri GM, Gende LB, Elissondo MC. In vitro and in vivo efficacy of carvacrol against Echinococcus granulosus. Acta Trop. 2016;164:272-9.
52. Khosravi AR, Franco M, Shokri H, Yahyaraeyat R. Evaluation of the effects of Zataria multiflora, Geranium pelargonium, myrrh and lemon essences on immune system function in experimental animals. J Vet Res. 2007;62:119-23.

53. Andersen A. Final report on the safety assessment of sodium $\mathrm{p}$-chloro-mcresol, p-chloro-m-cresol, chlorothymol, mixed cresols, m-cresol, o-cresol, p-cresol, isopropyl cresols, thymol, o-cymen-5-ol, and carvacrol. Int J Toxicol. 2006;25:29-127.

\section{Publisher's Note}

Springer Nature remains neutral with regard to jurisdictional claims in published maps and institutional affiliations.
Ready to submit your research? Choose BMC and benefit from:

- fast, convenient online submission

- thorough peer review by experienced researchers in your field

- rapid publication on acceptance

- support for research data, including large and complex data types

- gold Open Access which fosters wider collaboration and increased citations

- maximum visibility for your research: over $100 \mathrm{M}$ website views per year

At BMC, research is always in progress.

Learn more biomedcentral.com/submissions 